УДК 341.1

DOI https://doi.org/10.32849/2663-5313/2021.4.43

\title{
Свген Білоусов,
}

докт. юрид. наук, доцент,

професор кафедри права Європейського Союзу

Начіонального юридичного університету імені Ярослава Мудрого

\section{Марина Кахнова,}

студентка

Інституту прокуратури і кримінальної юстииії

Начіонального юридичного університету імені Ярослава Мудрого

\section{ЗАСТОСУВАННЯ СТАТТІ 10 КОНВЕНЦІЇ ПРО ЗАХИСТ ПРАВ ЛЮДИНИ I ОСНОВОПОЛОЖНИХ СВОБОД У ПРАКТИЦІ ЄВРОПЕЙСЬКОГО СУДУ 3 ПРАВ ЛЮДИНИ}

Стаття присвячена аналізу окремих аспектів застосування права на свободу вираження поглядів у практиці Свропейського Суду з прав людини.

Авторами ретельно досліджено складові елементи права на свободу вираження поглядів та проаналізовано актуальну практику Свропейського Суду з прав людини щодо кожної складової частини ивого права.

У дослідженні автори звертають увагу на те, що система захисту свободи вираження поглядів, що закріплена в Конвениії про захист прав людини і основоположни свобод за своєю правовою природою є багатоаспектною, оскільки надає особі право дотримуватися своїх поглядів, право на поширення інформачї̈ та ідеї; право на одержання інформації. Право на свободу дотримуватися поглядів означає можливість для кожної особи мати власну позииію щодо того чи іншого питання, при ивому гарантується також захист особи від приписування їй певної позиції на основі ї̈ попередніх висловлювань і негативних наслідків, які можуть виникнути з цього, а також міститься заборона щодо примушення особи розголошувати іншим власну позицію. Свобода одержувати і передавати інформацію та ідеї без втручання органів державної влади є другим елементом права на свободу вираження поглядів. При цвому право на свободу отримання інформації включає право на збір інформації, пошук інформації через усі можливі законні джерела й не лише стосується засобів масової інформації, але й надає право громадськості бути належним чином поінформованою, зокрема, з питань, що становлять суспільний інтерес.

У статті аргументовано доводиться, що на підставі аналізу практики Європейського Суду з прав людини можна говорити про доцільність та необхідність виокремлення чотирьох критеріїв, за якими обмеження доступу до інформаиії може визнаватися втручанням у реалізаиію свободи вираження поглядів. Отже, ними є мета запитувача (для чого потрібна інформачія), природа (характер) інформачії, роль запитувача, «готовність та доступність» інформачії. У дослідженні зазначено, ио право на передання інформації також входить до складу свободи вираження поглядів. При иьому аналіз практики Європейського Суду з прав людини дає підстави стверджсвати, що є певні типи висловлювань, які захищаються Конвенцією про захист прав людини і основоположних свобод, висловлювання, за допомогою яких передається інформаиія, не обмежуються лише написаними словами або усними висловлюваннями, під поняття «передання інформацї̈ можуть також підпадати зображення, фотографії і навіть культурна спадщина, які призначені для висловлення ідеї або подання інформаиії.

Авторами зроблено висновок про те, що не будь-які висловлювання захищаються статтею 10 Конвениії про захист прав людини і основоположних свобод. Зокрема, захист не поширюється на так звані hate speеch, тобто висловлювання, що підбурюють до ненависті чи насильства проти окремих релігійних груп, начіональних меншин, гендерних груп тощо та суперечать статті 17 Конвениї̈ про захист прав людини і основоположних свобод, яка встановлює заборону щодо зловживання правами.

У статті проведено аналіз так званого трискладового тесту, який використовує Європейський Суд з прав людини під час вирішення питання про наявність порущень статті 10 Конвениї̈про захист прав людини і основоположних свобод (the three-part test), а саме законність обмежень, легітимна мета, заради якої застосовувалось обмеження, та необхідність у демократичному суспільстві.

Ключові слова: свобода вираження поглядів, практика Європейського Суду з прав людини, доступ до інформації, передання інформації, «мова ненависті», «трискладовий тест». 
Постановка проблеми. Ратифікація Україною Свропейської конвенції про захист прав людини і основоположних свобод (далі - Конвенція), необхідність демократизації та утвердження плюралізму в громадянському суспільстві, застосування національними судами у своїх рішеннях практики Європейського Суду з прав людини (далі ЄСПЛ, Суд) вимагають ретельного аналізу права на свободу вираження поглядів, його складових частин та випадків легітимного обмеження цього права державою-учасницею Конвенції.

Питання змісту права на свободу вираження поглядів у практиці ЄСПЛ було предметом дослідження таких науковців, як К.В. Можаровська, О.І. Нагнічук, В.В. Середюк, Т.М. Слінько, С.В. Шевчук, Л.В. Ярмол. Водночас звернення до рішень ЄСПЛ з питань застосування статті $10 \mathrm{Koн}-$ венції та виявлення нових тенденцій Судом у тлумаченні права на вираження поглядів не втрачає своєї актуальності й зумовлює необхідність проведення подальших наукових досліджень.

Метою статті є розгляд основних складових частин права на свободу вираження поглядів в контексті звернення до актуальної практики ССПЛ з питань тлумачення ॥ ним положень статті 10 Конвенції.

Виклад основного матеріалу. Генеза права на свободу вираження поглядів сягає середини XX століття, адже 10 грудня 1948 року Генеральною Асамблеєю ООН було прийнято Загальну декларацію прав людини, яка, хоч і мала рекомендаційний характер, однак заклала підвалини створення міжнародно-правового механізму захисту прав людини і основоположних свобод.

Стаття 19 вищезазначеного міжнародного акта передбачає право кожної людини на свободу переконань і на вільне їх виявлення, що включає свободу безперешкодно дотримуватися своїх переконань та свободу шукати, одержувати й поширювати інформацію та ідеї будь-якими засобами незалежно від державних кордонів. Зауважимо, що обмежень цього права стаття 19 не містить. Зміст права на свободу вираження поглядів в подальшому був розвинений у Міжнародному пакті про громадянські і політичні права (далі - Пакт), який набув чинності 23 березня 1976 року. В Пакті вперше було передбачено вичерпний перелік випадків легітимного обмеження права на свободу вираження поглядів. Частина 3 статті 19 Пакту, зокрема, містить правило, згідно з яким користування правом покладає особливі обов'язки та особливу відповідаль- ність, тому може бути пов'язане 3 певними обмеженнями, які, однак, мають встановлюватися законом і бути необхідними для поваги прав і репутації інших осіб; для охорони державної безпеки, громадського порядку, здоров'я чи моральності населення. В подальшому в межах утвореного у 1949 році міждержавного об'єднання, а саме Ради Європи, було розроблено та прийнято «революційний» міжнародно-правовий документ - Конвенцію, яка стала фактично першоосновою створення та подальшого функціонування дієвого механізму захисту прав і свобод людини на міждержавному рівні. Слід зазначити, що створена система захисту прав людини і основоположних свобод протягом усіх років її існування неодноразово піддавалася ревізії через розроблення та прийняття Протоколів до Конвенції, які є її невід'ємною частиною. В контексті цього дослідження можна стверджувати, що положення статті 10 Конвенції щодо їх тлумачення Судом органічно пов'язані 3 принципами правоінтерпретаційної діяльності ЄСПЛ, тому втручання у право особи на свободу вираження поглядів становитиме порушення статті 10 Конвенції, якщо воно не підпадатиме під один з винятків, установлених частиною 2 статті 10 Конвенції. Окрім того, варто зазначити, що у вітчизняній доктрині свободу вираження поглядів розуміють у подвійному значенні: з одного боку, це надбання суспільства загалом, що гарантується державою-учасницею Конвенції, а 3 іншого боку, це право кожної особи, що перебуває під юрисдикцією держави-учасниці дотримуватися своїх поглядів, одержувати й передавати інформацію та ідеї без втручання органів державної влади і незалежно від кордонів. 3 цього випливає, що в разі невиконання державою своїх зобов'язань за статтею 10 Конвенції (у разі порушення цього права державою-учасницею) порушуються інтереси всього суспільства загалом, руйнується демократична основа держави.

Як слушно зазначають Т.М. Слінько та B.В. Середюк, закріплене у статті $10 \mathrm{KoH}^{-}$ венції право на свободу вираження поглядів $є$ одним із найбільш вагомих для розуміння природи демократичного суспільства [1, с. 580]. Більш того, на думку німецького вченого-юриста Й.А. Фровейна, без широких гарантій права на свободу вираження поглядів, захищених незалежними та неупередженими судами, немає вільної країни [2]. Ми погоджуємося з такими висновками дослідників і вважаємо, що рівень захисту свободи вираження поглядів в суспільстві не лише впливає на перебіг політичних процесів у державі та рівень демократії, але й посі- 
дає центральне місце у розвитку кожної людини - члена суспільства як особистості.

Структурно статтю 10 Конвенції можна поділити на дві частини. Перша частина визначає свободи, що захищаються Конвенцією, а друга встановлює вичерпний перелік обмежень (серед них слід назвати загрозу національній безпеці, територіальній цілісності або громадській безпеці, запобігання заворушенням чи злочинам, охорону здоров’я чи моралі), які дають змогу державі в легітимний спосіб втручатись та обмежувати здійснення цього права.

Свобода дотримуватися поглядів як складова частина права, передбаченого статтею 10 Конвенції, надає право особі мати власну позицію щодо того чи іншого питання, гарантує захист особи від приписування їй певної позиції на основі її попередніх висловлювань і негативних наслідків, які можуть виникнути з цього, а також забороняє примушувати особу розголошувати іншим свою позицію [3]. Держави не повинні намагатися розрізняти осіб, які дотримуються тієї чи іншої думки. Більше того, просування односторонньої інформації державою може становити серйозну і неприйнятну перешкоду свободі дотримуватися поглядів [4, с. 13].

Так, у справі «Фогт проти Німеччини» (рішення № 1 7851/9) заявниця, громадянка ФРН, отримавши необхідний стаж викладацької діяльності і склавши державні іспити, необхідні для заняття посади вчителя в гімназії, була призначена на таку посаду, що дало їй статус чиновника на державній службі. Громадянка Фогт була членом Німецької комуністичної партії з 1972 року, причому цей факт своєї біографії вона не приховувала. Пізніше проти неї було розпочато дисциплінарне переслідування, оскільки, на думку влади, вона здійснювала політичну діяльність, несумісну з нормами федерального й земельного законодавства про державну службу, вона не була «політично лояльна» і вірна Конституції. В подальшому влада округу тимчасово відсторонила пані Фогт із посади. Зрештою, було прийнято рішення про її звільнення як дисциплінарного стягнення. Суд у своєму рішенні зазначив, що права доступу на державну службу не випадково немає в тексті Конвенції, а відмова провести призначення будь-якої особи на державну службу не може слугувати підставою для скарги відповідно до положень Конвенції. Однак це не означає, що особа, яка знаходиться на державній службі, не може скаржитися на своє звільнення, якщо таке звільнення порушує одне з їі прав, що захищаються Конвенцією. Відповідно, статус штатного державного службовця, який пані Фогт придбала у зв'язку з її призначенням учителем середньої школи, не позбавляє її гарантій статті 10 Конвенції. До того ж Суд не знайшов доказів того, що сама заявниця на практиці виступала 3 будь-якими антиконституційними заявами навіть поза роботою або особисто займала в будь-чому антиконституційну позицію. Відповідно, Суд констатував порушення статті 10 Конвенції і дійшов висновку про те, що свобода дотримуватися думки включає захист особи від можливих негативних наслідків у випадках, коли їй приписуються ті чи інші погляди після попередніх публічних висловлювань. Свобода дотримуватись поглядів також включає «негативну свободу», коли особу не змушують повідомляти власні думки [5].

Свобода одержувати інформацію та ідеї без втручання органів державної влади і незалежно від кордонів є другим елементом права на свободу вираження поглядів. При цьому свобода отримання інформації включає право на збір інформації, пошук інформації через усі можливі законні джерела. Незважаючи на те, що свобода отримання інформації та ідей стосується засобів масової інформації, проаналізувавши наявну практику ЄСПЛ, розуміємо, що право на одержання інформації та ідей (без втручання органів державної влади та незалежно від кордонів) має громадськість, яка повинна бути належним чином поінформована, зокрема, 3 питань, що становлять суспільний інтерес. Показовою у цьому контексті є справа «Угорський Гельсінський Комітет проти Угорщини», за результатами розгляду якої ССПЛ запропонував чотири критерії, відповідно до яких обмеження доступу до інформації може визнаватися втручанням у реалізацію свободи вираження поглядів.

По-перше, це мета запитувача або те, для чого потрібна інформація. Так, у згадуваній справі неурядова організація Угорщини, здійснюючи контроль за дотриманням прав людини, звернулась до департаментів поліції з проханням надати імена призначених ними в тому році громадських захисників, а також інформацію щодо кількості призначень. Неурядовій організації було відмовлено, оскільки така інформація не становить інтерес у суспільстві. Однак ЄСПЛ зазначив, що інформація, запитувана заявником у поліції, перебувала, безперечно, в межах предметної сфери його досліджень. Для того щоби мати можливість підтримувати свої аргументи, заявник бажає зібрати номінативну інформацію про окремих адвокатів, щоби продемонструвати будь-які моделі призначення, що повторюються. Якщо б заявник обмежив свій запит анонімної 
інформації, як це було запропоновано Урядом, цілком ймовірно, він не був би в змозі надати результати, які можна перевірити, в підтримку своєї критики наявної схеми, тому інформація була «необхідною» для здійснення заявником свого права на свободу вираження поглядів.

По-друге, це природа (характер) інформації. Щодо характеру інформації Суд у цій справі зазначив, що національні органи влади не зробили ніяких оцінок стосовно характеру потенційного громадського інтересу запитуваної інформації та були зацікавлені тільки статусом державних захисників із точки зору Закону про дані. Останнє дало змогу обмежити винятки із загального правила про нерозголошення персональних даних. Водночас, на думку Суду, інформація про призначення громадських захисників становила значний суспільний інтерес незалежно від того, чи можна було віднести громадських захисників до «інших осіб, які виконують державні обов'язки», згідно 3 відповідним національним законодавством.

По-третє, це роль запитувача. Угорський Гельсінський Комітет був відомою організацією із захисту громадського інтересу, що займалась поширенням інформації з питань прав людини й верховенства закону. Суд констатував, що запитувана інформація була необхідна для виконання заявником цього завдання

По-четверте, це «готовність та доступність» інформації. Запитувана інформація була готовою й доступною, тому іï надання не було б обтяжливим для влади, отже, Суд не розглядав цей критерій, оцінивши обставини справи, виходячи із зазначених критеріїв.

Суд загалом дійшов висновку по справі, що мало місце втручання в право неурядової організації, передбачене статтею 10 Конвенції. Хоча таке втручання було передбачене законом і переслідувало законну мету (захист прав інших осіб), воно не було «необхідним у демократичному суспільстві». Отже, Суд постановив, що був факт порушення статті 10 Конвенції [6].

Слід зазначити, що право на передання інформації також входить до системи захисту свободи вираження поглядів, яка встановлена в Конвенції. При цьому аналіз практики ЄСПЛ дає нам підстави стверджувати, що є певні типи висловлювань, які захищаються Конвенцією. Можна говорити, що висловлювання, за допомогою яких передається інформація, не обмежуються лише написаними словами або усними висловлюваннями, під поняття «передання інформації» можуть також підпадати зображення, фотографії і навіть культурна спадщина, які призначені для висловлення ідеї або подання інформації.

Варто наголосити на тому, що з огляду на практику Суду форма вираження ідей також охороняється згідно зі статтею 10 Конвенції. Так, у справі «Швидка проти України» заявниця стверджувала, що, відірвавши від покладеного Президентом Януковичем вінка стрічку з написом «Президент України В.Ф. Янукович», вона висловила свою цілковиту незгоду з його політикою, включаючи утиски опозиції. За іiї твердженнями, цей вчинок також мав на меті виразити їі протест щодо ув'язнення опозиційного лідера пані Юлії Тимошенко. Більш того, заявниця прагнула показати своє розчарування обмеженнями, встановленими для громадськості у зв'язку із заходами щодо забезпечення безпеки Президента Януковича під час проведення офіційної церемонії покладання вінка. Вона наголошувала на тому, що не пошкоджувала вінок та не порушувала громадський порядок.

У цій справі ЄСПЛ погодився з тим, що своїм вчинком вона прагнула поширити серед людей навколо неї певні ідеї щодо Президента України, тому цей вчинок можна вважати формою вираження політичних поглядів. Відповідно, Суд зазначив, що застосування до заявниці за цей вчинок стягнення у вигляді десятиденного адміністративного арешту становило втручання у ії̈ право на свободу вираження поглядів. Водночас ЄСПЛ у цій справі, застосувавши «трискладовий тест» (про який нами буде зазначено далі), встановив, що законодавство, на підставі якого було застосовано адміністративний арешт, було передбачуваним, мета обмеження права була легітимною, зокрема заявниця вдалася до провокативного жесту, який міг занепокоїти або образити деяких людей, які були його свідками (такий захід був необхідний для забезпечення громадської безпеки), однак покарання у вигляді арешту було надмірним і непропорційним переслідуваній меті [7].

В контексті дослідження можна констатувати, що не будь-яке передання інформації захищається статтею 10 Конвенції. Йдеться про так звані hate speech (мова ненависті), incitement to violence (підбурювання до насильства), де існує навмисне та безпосереднє використання формулювань для підбурювання до насильства, а також реальна можливість того, що насильство відбудеться. Ці висловлювання не підпадають під захист, передбачений статтею 10 Конвенції.

Так, у справі «Вейделанд та інші проти Швеції» 60 заявників були засуджені за 
розподіл листівок в середині школи, які, на думку національних судів, були образливими для гомосексуалістів. Заявники поширювали листівки від організації під назвою «Національна молодь», залишаючи їх у шафах учнів або на них. В листівках були, зокрема, твердження, що гомосексуалізм має «морально-руйнівний вплив на сутність суспільства» і є відповідальним за розвиток ВІЛ та СНІДу.

ЄСПЛ по цій справі встановив, що ці заяви мали серйозні та упереджені твердження, навіть якщо в них були відсутні прямі заклики до актів ненависті. Суд наголосив на тому, що дискримінація за ознакою сексуальної орієнтації є такою ж серйозною, як і дискримінація за расою, походженням або кольором. Він дійшов висновку, що порушення Конвенції не було, а втручання держави у реалізацію заявниками права на свободу вираження поглядів було обгрунтованим [8].

В іншій справі, «Норвуд проти Сполученого Королівства», заявник виставив у своєму вікні плакат, наданий Британською національною партією, членом якої він був, де було зображено вежі-близнюки у полум'ї. Картина супроводжувалася словами «Іслам з Британії - захищай британський народ!». Як наслідок, він був засуджений за розпалювання ворожнечі до релігійної групи. Суд визнав скаргу неприйнятною, посилаючись на статтю 17 Конвенції, яка забороняє будьяку діяльність, «спрямовану на скасування будь-яких прав та свобод, визнаних Конвенцією». Суд зазначив, що свобода вираження поглядів не може використовуватися для знищення прав та свобод, викладених у Конвенції. Така атака на релігійну групу, ототожнення релігійної групи загалом із тяжким актом тероризму є несумісними 3 проголошеними та гарантованими цінностями Конвенцією, зокрема такими як, толерантність, мир у суспільстві та недискримінація. Таким чином, будь-який вираз, що містить елементи релігійної дискримінації, виходить за межі дії статті 10 Конвенції [9].

Отже, виходячи з аналізу практики Суду, ми вважаємо, що не будь-які висловлювання захищаються статтею 10 Конвенції. Зокрема, так звані hatespeech, тобто висловлювання, що підбурюють до ненависті чи насильства проти окремих релігійних груп, національних меншин, гендерних груп та суперечать статті 17 Конвенції, яка встановлює заборону щодо зловживання правами окремою державою, групою чи особою (тобто забороняє здійснювати діяльність або вчиняти будьякі дії, спрямовані на скасування будь-яких прав і свобод, визнаних Конвенцією, або на їх обмеження в більшому обсязі, ніж це передбачено в Конвенції).

Як уже зазначалось нами, у частині 2 статті 10 Конвенції передбачено вичерпний перелік випадків правомірного обмеження права на свободу вираження поглядів. При цьому ЄСПЛ, розглядаючи ту чи іншу справу, застосовує так званий трискладовий тест (the three-part test): законність обмежень, легітимна мета, заради якої застосовувалось обмеження, та необхідність у демократичному суспільстві.

Щодо законності втручання, то ЄСПЛ здійснює перевірку щодо наявності застосованих до заявника обмежень у законах держави-учасниці Конвенції. Як правило, це має бути письмовий та публічний закон, прийнятий парламентом, і саме національний парламент повинен «узаконити» таке обмеження. Наприклад, у справі «Санді Таймз проти Сполученого Королівства» Суд наголошує на тому, що норма права не може розглядатися як «закон», якщо вона не сформульована достатньо точно і чітко, щоб громадянин міг регулювати свою поведінку. Також закон має бути загальнодоступним, аби громадянин за необхідності міг передбачити наслідки своїх дій.

Легітимна мета передбачає, що перелік можливих підстав для обмеження свободи вираження поглядів є вичерпним. Державні органи чи посадові особи держави не можуть свавільно виходити за межі переліку обмежень, що встановлені в частині 2 статті 10 Конвенції. Тільки за умови ствердної відповіді щодо наявності легітимної мети національні суди можуть застосувати визначені Конвенцією обмеження до відповідної особи. Наприклад, вилучення нецензурної книги може мати законну мету захистити мораль, однак судова заборона проти публікації секретної інформації в газетах може бути виправдана інтересами національної безпеки. Суди повинні враховувати, що інтерес, який потребує захисту, має бути реальним, а не можливим. Якщо ж національний суд дійде висновку про наявність законного обмеження та легітимну мету такого обмеження, суд приймає рішення, що таке втручання $є$ «необхідним у демократичному суспільстві».

Слід зазначити, що для прийняття рішення відповідно до третьої вимоги тесту національні суди повинні застосовувати принцип пропорційності, відповідаючи на таке запитання: «Чи була мета пропорційна засобам, використаним для iĭ досягнення?». У цьому питанні мета - це одна або більше цінностей, інтересів, передбачених частиною 2 статті 10 Конвенції, для захисту яких 
держави можуть втручатися у свободу вираження поглядів. Засобом є саме втручання. Отже, мета - це конкретні інтереси, на які посилається держава, такі як національна безпека, порядок, мораль, права інших, а засіб - це конкретний обмежувальний захід, який застосовується до особи, яка реалізує своє право на свободу вираження поглядів. Наприклад, засобом може бути заборона публікації, обшук приміщення газети. Можна констатувати, що рішення про пропорційність базується на принципах демократичного суспільства. Для того щоб довести, що втручання було «необхідним у демократичному суспільстві», потрібно переконатися в тому, що існує «нагальна соціальна потреба», що вимагає цього конкретного обмеження щодо реалізації свободи вираження поглядів. Так, у справі «Обсервер та Гардіан проти Сполученого Королівства» ССПЛ зазначив, що прикметник «необхідний» у межах значення пункту 2 статті 10 передбачає існування «надзвичайної соціальної ситуації». Саме така ситуація виправдовує обмеження права на вираження поглядів, що передбачене статтею 10 Конвенції.

\section{Висновки}

Конвенцією було встановлено певні міжнародні стандарти, яких повинні дотримуватися держави-учасниці у їх взаємовідносинах з будь-якою особою, що перебуває під їхньою юрисдикцією, при цьому гарантувати забезпечення реального й ефективного захисту прав і свобод людини, які передбачені Конвенцією та Протоколами до неї. Це твердження повною мірою стосується права на свободу вираження поглядів, передбаченого статтею 10 Конвенції. Структурно статтю 10 Конвенції можна поділити на дві частини. Першою є складові частини права на свободу вираження поглядів, другою - вичерпний перелік легітимних обмежень досліджуваного права. Свобода дотримуватися своїх поглядів включає право особи мати власну позицію щодо того чи іншого питання, гарантує захист особі від приписування їй певної позиції на основі її попередніх висловлювань і негативних наслідків, які можуть виникнути з цього, а також забороняє примушувати особу розголошувати іншим свою позицію. Свобода одержувати інформацію передбачає можливість для засобів масової інформації отримувати iї будь-якими незабороненими засобами та право громадськості отримувати суспільно необхідну інформацію. Свобода передання інформації являє собою не лише написані слова або усні висловлювання, але й зображення, фотографії і навіть культурну спадщину, що призначені для висловлення ідеї або подання інформації. При цьому статтею 10 Конвенції захищається не тільки сама ідея, але й форма їі вираження. Вирішуючи питання про наявність у справі порушення статті 10 Конвенції ЄСПЛ застосовує так званий трискладовий тест (the three-part test): законність обмежень, легітимна мета, заради якої застосовувалось обмеження, та необхідність у демократичному суспільстві.

\section{Список використаних джерел:}

1. Слінько Т.М., Середюк В.В. Свобода вираження поглядів у рішеннях Європейського суду з прав людини та загальні критерії її обмеження. Форум права. 2009. № 3. С. 580-585. URL: http://www.nbuv.gov.ua/e-journals/FP/2009-3/ 09ctmkio.pdf.

2. Jochen Abr. Frowein, "Freedom of expression under the European Convention on HumanRights", in Monitor/Inf (97) 3, Council of Europe.

3. Лутковська В.В. Конвенції про захист прав і основних свобод людини. URL: http://www. judges.org.ua/article/seminar14-7.htm.

4. Protecting the right to freedom of expression under the European convention on human rights. URL: http://www.inai.tn/wp-content/ uploads/2018/11/20170718_Handbook-Freedomof-Expression-ENG.pdf.pdf.

5. Дело «Фогт (VOGT) против Германии». URL: https://europeancourt.ru/uploads /ECHR_ Vogt_v_Germany_26_09_1995.pdf.

6. Справа «У горський Гельсінський комітет проти Угорщини». URL: https://cedem.org.ua/ library/13522.

7. Справа «Швидка проти України» (Заява № 17888/12). URL: https://zakon.rada.gov.ua/ laws/show/974_a40\#Text.

8. Case of Vejdeland and others v. Sweden. URL: file://C:/Users/1/Downloads/001-109046.pdf.

9. Norwood v. the United Kingdom. URL: file:///C:/Users/1/Downloads/001-67632.pdf.

10. Sunday Times v. the United Kingdom: Judgment 26 April 1979. URL: http://cmiskp.echr. coe.int/tkp197/view.asp?item $=2 \&$ portal $=$ hbkm\&ac tion=html\&highlight=Sunday $\% 20 \% 7 \mathrm{C} \% 20$ Times\&s essionid $=67430 \&$ skin $=$ hudoc-en.

11. «Обсервер» i «Гардіан» проти Сполученого Королівства. URL: https://europeancourt.ru/ uploads/ECHR_Observer_and_Guardian_v_The_ United_Kingdom_26_11_1991. pdf. 
Yevhen Bilousov, Maryna Kakhnova. Application of Article 10 of the Convention for the Protection of Human Rights and Fundamental Freedoms in the case law of the European Court of Human Rights

The article focuses on the constituent elements of the right to freedom of expression and examines the multidimensional nature of the freedom of expression as a part of the right referred to in Article 10 of the European Convention on Human Rights. The latter protects the right of individuals to hold their own position on a particular issue, guarantees them the protection from attribution of the position based on previous statements and from those negative consequences that may arise from this. It also prohibits forcing a person to disclose his position to others. The freedom to receive information and ideas without interference by public authority and regardless of frontiers is the second element of the right to freedom of expression. At the same time, the freedom to receive information includes the right to gather and seek information through all possible legitimate sources and applies not only to the media, but also to the public who have the right to be properly informed about issues of public interest.

Having analyzed the practice of the European Court of Human Rights we distinguished four criteria by which restriction of the access to in formation can be considered as interference in exercising the right to freedom of expression: the purpose of the requester and what they need this information for; the nature of information, the role of the requester, "availability and accessibility" of information. Freedom of expression also includes the right to impart information. At the same time, the analysis of the practice of the European Court of Human Rights gives us grounds to say that there are certain types of statements protected by the European Convention on Human Rights. Expressions through which information is transmitted are not restricted to only written words or verbal expressions but may also include images, photographs and even cultural heritage intended to express an idea or present information.

We argue that not all statements are protected by Article 10 of the European Convention on Human Rights due to the fact that the protection does not cover hate speech, i.e. statements that encourage hatred or violence against certain religious groups, national minorities, gender groups, etc. and are contrary to Article 17 of the European Convention on Human Rights, which prohibits the abuse of rights.

We carried out the so-called the three-part test' which uses the European Court of Human Rights to identify the violations of Article 10 of the European Convention on Human Rights: legitimacy of such interferences, the legitimate aims pursued and the need for a democratic society.

Key words: freedom of expression in the practice of the European Court of Human Rights, access to information, transmission of information, "hate speech", "the three-part test". 